\title{
Facsimile imagery analysis on the history of acquired immunodeficiency syndrome
}

\author{
Análise imagética de fac-símile sobre a história da síndrome da imunodeficiência adquirida
}

Margarida Maria Rocha Bernardes ${ }^{1}$, Antonio Marcos Tosoli Gomes ${ }^{1}$, Fernando Rocha Porto ${ }^{2}$, Érick Igor dos Santos $^{3}$, Sônia Helena da Costa Kaminitz ${ }^{2}$

Objective: to demonstrate the use of the image as image inductor to the research of social memory in health and nursing from an emblematic image of the history of acquired immune deficiency syndrome. Methods: utilization of a matrix of image analysis with four items about the picture published in the Jornal o Globo newspaper of 09.28.1987, page 13. Results: the results were contextualized to the symbol image of a pandemic, through corresponding public media elements in the 1980s in Brazil. The attitudes of the nursing professional were highlighted, who is said infected by the human immunodeficiency virus in the work space, and this media subject published in a national newspaper. This is photojournalism that can serve as a tool for studies of social memory in health and nursing. Conclusion: the analysis of the matrix is ratified as a research tool of social memory and documentary image, applicable to nursing research.

Descriptors: HIV; Acquired Immunodeficiency Syndrome; Eidetic Imagery; Psychology, Social; Nursing.

Objetivo: demonstrar o uso de imagem como indutor imagético para as pesquisas de memória social em saúde e enfermagem a partir de uma imagem emblemática sobre a história da síndrome da imunodeficiência adquirida. Métodos: utilização de uma matriz de análise imagética com quatro itens sobre a imagem divulgada no Jornal O Globo de 28/09/1987, página 13. Resultados: os resultados foram contextualizados à imagem símbolo de uma pandemia, por meio de elementos públicos midiáticos correspondentes à década de 1980, no Brasil. Em destaque as atitudes da profissional de enfermagem que se diz contaminada pelo vírus da imunodeficiência humana no espaço laboral, sendo este assunto midiático publicado em um jornal de circulação nacional. Trata-se de fotojornalismo que pode servir como instrumento para estudos de memória social em saúde e enfermagem. Conclusão: a análise da matriz é ratificada como ferramenta de pesquisa de memória social e documental imagética, aplicável em pesquisas em enfermagem.

Descritores: HIV; Síndrome da Imunodeficiência Adquirida; Imagem Eidética; Psicologia Social; Enfermagem.

\footnotetext{
${ }^{1}$ Universidade do Estado do Rio de Janeiro. Rio de Janeiro, RJ, Brazil.

${ }^{2}$ Universidade Federal do Estado do Rio de Janeiro. Rio de Janeiro, RJ, Brazil.

${ }^{3}$ Universidade Federal Fluminense. Rio das Ostras, RJ, Brazil. 


\section{Introduction}

The 1970s was marked worldwide as the sexual liberation and change of existing paradigms, with the logo of peace and love, and Brazil following that sexual liberation movement. In this decade, we lived in the country significant changes in some important areas for the development and consolidation of the guidelines that came to make a difference in the governance of the country.

One decade later (1980) the military regime came to the end, going on the democratization of the country, when the first direct elections for the presidency of the country were held in 1988, with the approval of a new Constitution. At this time, in the midst of sexual liberation, a new health problem emerged in the global context, caused by the human immunodeficiency virus (HIV), acquired immunodeficiency syndrome (AIDS).

There are three phases described in the literature about the epidemic. The first from 1980 to 1986, emerged confirmed cases of the syndrome in the states of São Paulo, Rio de Janeiro and other cities in the Southeast and South, reaching homo/ bisexual people, male, high school, blood receptors and blood products. The second phase, described between 1987 and 1991 was marked by increased numbers of cases among injecting drug users, by the blood transfusion and the appearance of cases among heterosexuals, occurring simultaneous process of pauperization of users and internalization of the epidemic. The third was demarcated from 1992 to the present, through epidemiological analysis, suggesting respectable changes in the epidemic patterns in the country, having, for example, exponential increase in the number of cases through heterosexual exposure, differently from heterosexuals and feminization, internalization and outlined pauperization ${ }^{(1)}$.

The participation of nursing in the above stages is emphasized. This is due, because the purpose of taking care of people, considering the healthy state until the emergence of health problems, including educational activities and interventions, when necessary, during treatment ${ }^{(2)}$. Thus, in recent years of the twentieth century, politicized forms of living serologically positive for HIV/AIDS had emerged.

As an example, it is worth mentioning a newspaper article published in the Jornal $O$ Globo newspaper in 1987, entitled "Nurse from São Paulo contracted AIDS by treating prisoners with the disease." This matter was presented to readers with text and image. It is, in short, a report about the experience of a nursing professional who was living with HIV, in the first phase described in the literature looking after the affected by the disease virus.

Through the above, nursing professionals, when caring for people living with HIV/AIDS, bring with them social memories, inherent to this object. To access such memories it would be necessary to use inductor agents, named as an image in this text. They are, therefore, images able to behave like some mental trigger to bring out the psycho-social reconstruction of the past.

In the logic of this thinking, the image is imagingobject of the study. This implies the understanding that it is a potential to incorporate the oral reports and its photojournalism narrative, bringing life memories and professionals, to contribute to the construction of knowledge, when it can articulate image and other written documents.

The object image of study has incorporated the oral accounts and its photojournalism narrative, bringing a social memory of life and professional, in addition to contributions from opinion articles, manifestos, association newsletters, discussion forums that complement the oral sources in the seizure of photographic contemporary experience ${ }^{(3)}$.

Thus, it was aimed to demonstrate the use of an image as image inductor to the research of social memory in health and nursing, from an emblematic 
image of the history of acquired immune deficiency syndrome.

The justification for the fulfillment of the proposed objective is due to the possibility to socialize with those interested in the HIV/AIDS theme and studious in the use of the image with a documentary source, being possible to emerge some aspects of the lived experiences, concerning the nursing care.

\section{Methods}

This is a qualitative and descriptive research, carried out in the semiotics, understood as a designation of the signs science, which, on the one hand, refers to the Anglo-Saxon origin and semiology and on the other hand, the neo-Latin side of the European culture, as an autonomous discipline. Thus, quibbles apart, the semiotics term was adopted, with justification, through the Incorporation Letter of the International Association for Semiotic StudiesAssociation Internationale de Sémiotique, dated 1969, to its equivalence.

Another understanding to understand the purpose of this study is due to facsimile lexicon. It originates from the Latin, meaning as similar, through the exact copy of the document, whether photomechanical, electronic and electrostatic.

Another term should be clarified concerning the question of image memory, which was originated from the appearance of photography, in the nineteenth century and early twentieth century.

The images emerged and spread to contribute significantly to the expansion of what is called memory. The photograph, by contrast, crystallizes it. Thus, the use of photography as a souvenir tool recreates, symbolizes and recovers the past. The photos vivify. By its very documentary nature, photography takes us back to the past, questioning us on the present.

For this purpose, we used an image analysis matrix composed of four items, through two semiotic principles, namely expression plane and content to shown the analytical procedure of the image.
It is noted that the journalistic matter, presented in this study, was found during the search of media documentation, which was published on September $28^{\text {th }}, 1987$ in the Jornal O Globo newspaper, owner of its copyright. This image was, chronologically, the first found in the Brazilian Interdisciplinary AIDS Association.

The study complied with the formal requirements contained in the national and international standards of regulatory research involving human subjects.

\section{Results}

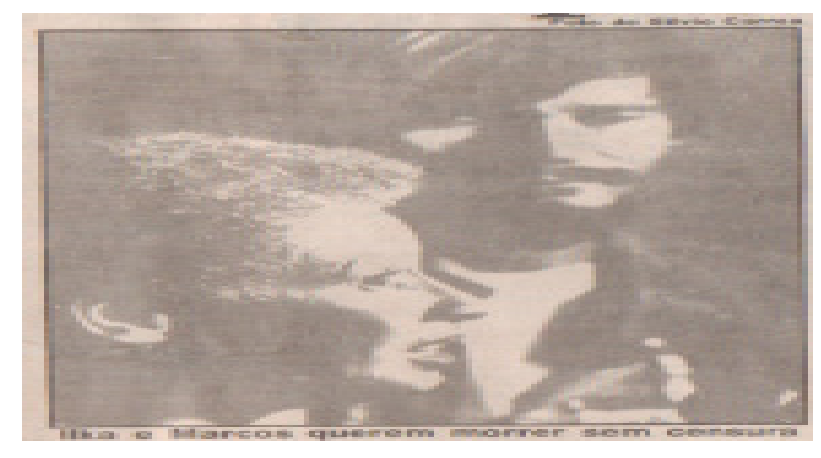

Figure 1 - Image extracted from the facsimile of the journalistic matter: "Nurse from Sâo Paulo contracted AIDS by treating prisoners with the disease," broadcast on 09.28.1987 in the Jornal O Globo newspaper

The photojournalism is titled "Nurse from São Paulo contracted AIDS by treating prisoners with the disease" and a subtitle "Laser identifies the virus in minutes", with a picture of the four columns without separating wires. The image was used for the demonstration of the use of images as image inductors for research on the topic of HIV/AIDS. The analysis matrix concerns the figure of the couple who is portrayed in the facsimile. It is Ilka and Marcos, named in the journalistic matter.

From this moment, the application of the analysis matrix is presented and then, the strategy for text construction with the extracted data, showing a demonstration of the image use, as image inductor in 
the HIV/AIDS theme (Figures 2, 3, 4 and 5).

It proceeded to the memory induction of the participants via image, that is, their speech was activated on existing images in various media. The image, therefore, constituted a source for the rescue of the moments lived in that context of HIV/AIDS, in the 1980s, in Rio de Janeiro.

\begin{tabular}{|l|l|}
\hline \multicolumn{2}{|c|}{ Identification data } \\
\hline Collection local & $\begin{array}{l}\text { Collection of the Brazilian Interdisci- } \\
\text { plinary AIDS Association. Rio de Janeiro }\end{array}$ \\
\hline Name of the magazine/newspaper & Jornal O Globo newspaper \\
\hline Year of publication & 1987 \\
\hline Copy number & Without identification \\
\hline Page with the photographic image & Page 13 \\
\hline $\begin{array}{l}\text { Publication date of the magazine } \\
\text { copy }\end{array}$ & 09.28 .1987 \\
\hline Title or headline that accompanies & $\begin{array}{l}\text { Title: Nurse from São Paulo contracted } \\
\text { disease }\end{array}$ \\
\hline
\end{tabular}

Figure 2 - Analysis matrix (data identification)

\begin{tabular}{|l|l|}
\hline \multicolumn{2}{|c|}{ Data for the expression plane } \\
\hline Photography image credit & Silvio Correia Photo \\
\hline Text-image relationship & Photojournalism \\
\hline Photographic image subtitle & Ilka and Marcos want to die uncensored \\
\hline Text summary & $\begin{array}{l}\text { Testimony of nursing assistant of the } \\
\text { Penitentiary of São Paulo state }\end{array}$ \\
\hline Photo type & Ilka and Marcos-posing \\
\hline Format & Rectangular \\
\hline Plan & Ilka and Marcos foreground. \\
\hline Photo sense & Vertical \\
\hline Page Image localization & Figure n.1.1 next to zones 5 and 6 \\
\hline
\end{tabular}

Figure 3 - Analysis matrix (expression plan)

\begin{tabular}{|l|l|}
\hline \multicolumn{2}{|c|}{ Data for content plan } \\
\hline $\begin{array}{l}\text { Portrayed local } \\
\text { The portrayed local is the shooting scene }\end{array}$ & Not identified \\
\hline $\begin{array}{l}\text { Portrayed bottom } \\
\text { Portrayed bottom: natural or artificial and } \\
\text { internal or external }\end{array}$ & Without evaluation conditions \\
\hline Portrayed persons & Ilka and Marcos (mixed group) \\
\hline Theme of the portrayed images & AIDS (social political) \\
\hline Personal attributes & Ilka and Marcos \\
\hline Landscape attributes & Without evaluation conditions \\
\hline
\end{tabular}

Figure 4 - Analysis matrix (content plan)

\begin{tabular}{|l|l|}
\hline \multicolumn{2}{|c|}{ Complementary data obtained from other photographic image } \\
\hline Information origin & $\begin{array}{l}\text { Printed media. There were not extra } \\
\text { information in addition to the screen report } \\
\text { matter }\end{array}$ \\
\hline Complementary information & Not applicable \\
\hline
\end{tabular}

Figure 5 - Analysis matrix (complementary data)

\section{Discussion}

There is the need to clarify that in photojournalism, images are accompanied by texts, so that the whole will approximate the real ${ }^{(4-8)}$. Regarding the photography type, it is clear that they can be classified as posing or instant (flagrant) and came to be used in the mid-1920s. The innovation contemplated the photography of people without them noticing or the denominated instant technique. This practice of spontaneous or sincere photo, which later would become the basis of photojournalism, liberate the photography, restricted to posing photo, allowing differentiated visualization and giving to the photographic technique the function of representing reality ${ }^{(9)}$. In the case of the photo in question, present in this facsimile, it was apparently posing.

Regarding the type of photographic plan, here are the following classifications, namely: general plan, when portraying large rooms, usually on the outside; joint plan aimed at people when they are not the central photo objects; central plan, where people are the center plan of the photo; American plane is the plane in which people are portrayed from the waist up; foreground, known as close of people or objects; and the detail plan, the first variant at its maximum representation ${ }^{(10)}$.

In Figure 4, specifically in the question portrayed people, we need to clarify who are the people and if the picture is individual or in a group (male, female or mixed); as the subject of the portrayed image refers to the type of event (social, political, religious or institutional); as the landscape attributes, 
objects that appear in the image, characteristic of the portrayed scene, elements present in the composition of the scene.

About personal attributes it is possible to describe personal garments, clothing, and gestures, attitudes, and accessories that people boast. Therefore, it can be affirmed that Ilka was portrayed in profile, half-open lips and makeup with furrowed brow. Marcos was portrayed facing the camera lens. His look is directed to his wife, Ilka. He boast a beard, outlining lips, clenched and face contour. He wears a light-colored shirt and other clothes, jacket or windbreaker, dark tone, open, making contrast in light and dark shades.

This is a propagator image on page 13 , at the Jornal O Globo newspaper, dated 09.28.1987, with journalistic matter entitled "Nurse from São Paulo contracted AIDS by treating prisoners with the disease", with the content, in short, the testimony of nursing assistant of the Penitentiary the of São Paulo State, Ilka dos Santos Pozan, 35 years old, saying during the II International Conference on AIDS, which took place at the end of the week before the report, which contracted the disease in contact with prisoners with AIDS. She was portrayed in the matter with her husband Marcos Makarewjcz, 41 years old.

In the image, it is possible to identify two people portrayed in the rectangular geometric shape, flagrant type, in the foreground, in the vertical direction of the journalistic matter. The portrayed by the subtitle are: Ilka (nursing assistant) and Marcos, Ilka's husband. She has as personal attributes, half-open and makeup lips, brow furrowed and he has his look directed to his wife Ilka. He boast a beard, outlining lips clenched, and face contour, costumes light-colored shirt and other clothes, jacket or windbreaker, dark tone that open, makes contrast of light and dark shades.

The assimilation of AIDS by the media and by different social groups, before the biological research proved scientific knowledge about the disease, emerged interpretations of moral and social, and other biological who came to bring harm to the relations established in people's lives, causing preexisting thoughts that led to a social morality, in the private and social sphere of individuals ${ }^{(11)}$.

It is emphasized that Figure 1 addresses the possible contamination of a nursing assistant in the profession in prison institution working with people living with HIV. She affirmed, during the II International Conference about AIDS, held in São Paulo, she would like to know how she was contaminated at work, believing to be responsible for the contagion of her husband. She refers relationship problems with the children, because of the couple's illness, and expects help from the country, medicine, and science, to obtain evidence that she acquired HIV in the workplace.

In the picture, Marcos, tight-lipped, intentionally looks at his wife. His eyes can be understood as a sign of strong meaning imbued, which can be decoded. Eyes, as ocular contact, are the most important tools of the body, because can evaluate the transmitters of vital social signals, being understood as a communication act with energy and emotion ${ }^{(12)}$.

Marco's clenched lips can signal that they close and exclude. In other words, who listen and closes the mouth, closes for us, refusing to understand what we are proposing them ${ }^{(13)}$. The exhibition of the couple in the media would have been an act of courage. To address the issue of AIDS in infected women has always been difficult, as it requires to emerge issues related to various aspects of women's intimate nature, such as marriage, motherhood, sexuality, gender relations and others ${ }^{(14)}$.

The gesture of Ilka in the image is with open eyes and half-open mouth. This denotes that normally to being surprised, two muscles of our eyelids (upper and lower tarsus), extend the eye sockets so that the eyes look rounder, larger and whiter. This physiological reaction happens when we get emotional or for some reason we feel threatened ${ }^{(12)}$.

Concerning the mouth, it is not an organ that has the unique function of receiving food. The 
representation of ajar gesture may indicate that it is willing to receive, listen, and drink what we are told. This can be decoded in awe-expression, and let to see a greater openness in the emotional sphere than in mental ${ }^{(13)}$.

Through body language of portrayed, it appears that the couple, perhaps, was uncomfortable when the photographic click was shot to record the photographic image as Ilka and Maros were in the II International Seminar about AIDS, where they probably met the holders of knowledge about the new syndrome at the time. It is understood that the suffering of people who lived/living with HIV goes beyond the physical sphere; it involves family and social conditions, with strong negative expression in their social, cultural and imaginary dimensions, revealing the existence of an awareness zone related to identity experienced by the patients ${ }^{(15)}$.

In this event, the professional staff rose to present and form its first technical specialists. The pressure to this epoch was big and the convened media needed images to face AIDS. The couple who gave their testimony was perhaps the ideal model to guide the content of which was transmitted to the other, in this case, readers.

Thus, communication is established as a means of action whose objectives are explained clearly enough to guide the content of what is transmitted to the other. The act of communicating acquires a kind of particular dignity because it is necessary to establish a relationship between the emitter and the receiver ${ }^{(16)}$.

The communication through photojournalism was a source that reported and showed records about HIV/AIDS through the image, in the first phase of the epidemic, when the HIV affected sought to remain unnoticed. Of course, the journalistic matter established the relationship between the emitter (newspaper) and the receiver (reader), bringing possible elements of analysis of the symbolic representation of the portrayed, an HIV-positive couple, where the women, nursing professional, attributed the occurring contamination to their labor activity of care ${ }^{(16)}$.

It is worth highlighting the role played by the photographic image in the eyes adjustment processes in the public space configuration, to fulfill a political function which ensures the transmission of a message to give visibility to the strategies of power, or even the power struggles.

The public photography is produced by image production agencies that play a role in developing a public opinion (media, state, and others) are, therefore, the support of a public memory that records, retains and designs, in history time, a version of events. This version is constructed by a visual and verbal narration, that is, inter-textual but also multitemporal. The version includes the event time, the time of its transcription by the narrative mode and the time of receipt in the historic landmark of its publication, scaled by the forms of their exhibition in the press, in museums, books, projects or others. Public photograph visually produces a public sphere in contemporary societies, in pace with the worldviews which is associated ${ }^{(16)}$.

Encoded the possible meanings of the image, the researcher can interview the participants of the conscious study of image codes.

\section{Conclusion}

After the demonstration of what has been proposed for the study, the images are realistic, representing the foretold tragedy.

It is recommended that, for the time of the interview with image inductors, research participants should have access to the images at the moment of collection of information, considering that they are image inductors to the questions in the construction process of the study object of knowledge because otherwise, there may be contamination of records, 
accelerating the process of memory before the desired time. The images may be used before starting the interviews, heating what will be covered in the interview, without thereby, being an articulation of the images presented to the interview, especially for the analysis and discussion of the data, in the sense of environment preparation, which also is meant as image inductor.

However, it must be clear, methodologically, which strategy should be used to the images in the investigation, that is, as image inductors for the social memory of the participants, without pretense of analytical articulation in testimony and images, i.e., image inductors with articulation that subjects will see and statements, including the representation of the presented images; or image inductors to sensitize the subject.

Anyway, it is up to the researcher to be clear about the image position in research. In the study with the focus on perception as construct in the context of psychic functions, where the memory is included, it is interesting to decode the contained meanings, to condition them to have a better command of the subject matter, because they can highlight specific visual phenomena that enable mental buildings anchored on social aspects, such as HIV/AIDS. Furthermore, it is noted, as a conclusion of the study, that the application of the matrix is a methodological tool for research, here demonstrated for the image applicable social memory in studies of health and nursing, and can be replicated in other studies.

\section{Collaborations}

Bernardes MMR, Gomes AMT, Porto FR, Santos ÉI and Kaminitz SHC collaborated in the project design, analysis and interpretation of data, article writing and relevant critical review of its intellectual content and final approval of the version to be published.

\section{References}

1. Villarinho MV, Padilha MI, Berardinelli LMM, Borenstein MS, Meirelles BHS, Andrade SR. Políticas públicas de saúde face à epidemia da AIDS e a assistência às pessoas com a doença. Rev Bras Enferm. 2013; 66(2):271-7.

2. Costa TL, Oliveira DC, Formoso GA. Representações sociais sobre pessoas com HIV/AIDS entre enfermeiros: uma análise estrutural e de zona muda. Estud Pesq Psicol. 2012; 12(1):242-59.

3. Maciel AM. 0 uso da imagem fotográfica no livro didático de matemática para jovens e adultos. Rev Temas Educ. 2011; 20(1):222-38.

4. Oliveira Neto M, Porto FR, Nascimento SA. Application of semiotics in the analysis of facsimiles: a documentary research. Online Braz J Nurs [Internet]. 2012 [cited 2015 Out 01]; 11(3):848-64. Available from: http://www. objnursing.uff.br/index.php/nursing/article/ view/3705 848.

5. Losada JZ. A figuração do longínquo: natureza, fotografia e sujeitos no Brasil nas fronteiras do século XIX. Topoi. 2014; 15(29):685-9.

6 Catela LS. Todos temos um retrato: indivíduo, fotografia e memória no contexto do desaparecimento de pessoas. Topoi. 2012; 13(24):111-23.

7. Fonseca EFR, Porto F. Fac-Símile research on the history of midwifery: inauguration of the chapel of the Pró-Matre (1923). Rev Pesq Cuid Fundam Online [periódico na Internet]. 2010 [cited 2015 Oct 01]; 2(4):1495-505. Available from:http://www.seer.unirio.br/index.php/ cuidadofundamental/article/view/1315/ pdf_236

8. Bastos, AR. The photography as a portrait of society. Sociologia. 2014; 28:127-43.

9. Mauad AM, Lopes MFB. Imagem, história e ciência. Bol Mus Para Emílio Goeldi Ciênc Hum. 2014; 19(2):283-6.

10. Bencostta ML. Memória e cultura escolar: a imagem fotográfica no estudo da escola primária de Curitiba. História. 2011; 30(1):397-411. 
11. Costa TL, Oliveira DC, Formozo GA. Social representations about the person with HIV/AIDS between nurses: a mute zone study. Estud Pesqui Psicol. 2012; 12(1):242-59.

12. Oliveira OS, Nóbrega MML, Silva ATMC, FerreiraFilha MO. Therapeutic communication in revealed nursing in the depositions of interned patients in center of intensive therapy. Rev Eletr Enferm [periódico na Internet]. 2010 [citado 2015 out 01];7(1):54-63. Disponível em: http:// www.revistas.ufg.br/index.php/fen/article/ view/861/1034

13. Miranda RS, Schubert CO, Machado WCA. Communication with people with hearing disabilities: an integrative review. Rev Pesq Cuid Fundam Online [periódico na Internet]. 2014 [citado 2015 out 01]; 6(4):1695-706. Disponível em:http://www.seer.unirio.br/index.php/ cuidadofundamental/article/viewFile/3204/ pdf_1223
14. Carvalho CML, Galvão MTG. Sentimento de culpa atribuídos por mulheres com aids face a sua doença. Rev Rene. 2010; 11(2):103-11.

15. Gomes AMT, Oliveira DC, Santos ÉI, Santo CCE, Valois BRG, Pontes APM. As facetas do convívio com o HIV: formas de relações sociais e representações sociais da AIDS para pessoas soropositivas hospitalizadas. Esc Anna Nery. 2012; 16(1):11120.

16. Pagliuca LMF, Barbosa GOL, Wanderley LD, Oliveira PMP. Analysis of the verbal and nonverbal communication of a blind mother with motor impairment during breastfeeding. Rev Bras Enferm. 2011; 64(3):431-7. 